\title{
A Note on Texts, Translations, and Transliteration
}

I have quoted from the following texts, unless I have indicated otherwise:

Aeschyli: Septem Quae Supersunt Tragoedias. Ed. Denys Page. Oxford: Oxford University Press, 1972.

Aristotelis Politica. Ed. W. D. Ross. Oxford: Oxford University Press, 1957.

Euripidis Fabulae. Vols. $\mathrm{I}$ and 2 ed. J. Diggle; vol. 3 ed. Gilbert Murray. Oxford: Oxford University Press, I98I, 1984, 1913.

Herodoti Historiae. Ed. C. Hude. Oxford: Oxford University Press, 1927.

Homeri Opera. Ed. David B. Monro and Thomas W. Allen. 5 vols. Oxford: Oxford University Press, 1902-1920; rpt. 1966.

Platonis Opera. Ed. John Burnet. 5 vols. Oxford: Oxford University Press, 1900.

Sophoclis Fabulae. Ed. A. C. Pearson. Oxford: Oxford University Press, 1924; rpt. 1975. [I have also consulted Sophoclis Tragoediae, ed. R. D. Dawe, 2 vols. (Leipzig: Teubner, 1984). Any significant variants from Pearson are indicated in the notes.]

Thucydidis Historiae. Ed. H. S. Jones. Oxford: Oxford University Press, 1898.

Unless I have indicated otherwise, the translations are my own. 
xviii A Note on Texts

Short passages cited from the Greek texts are transliterated according to the ALA Cataloguing Rules for Author and Title Entries (Chicago: American Library Association, 1949). Iota subscripts are indicated in parentheses or brackets. Names of characters, however, appear in the forms by which they have become familiar to modern readers: Achilles, Hector, Creon, Polynices, and so on. 


\section{Prophesying \\ Tragedy}


